\title{
Acute administration of nicotine does not enhance cognitive functions
}

\author{
Andrea Grus ${ }^{1}$ and Ivana Hromatko ${ }^{2}$ \\ ${ }^{1}$ Division of Psychology, University Department of Croatian Studies, University of Zagreb, Zagreb, Croatia \\ ${ }^{2}$ Department of Psychology, Faculty of Humanities and Social Sciences, University of Zagreb, Zagreb, Croatia
}

[Received in January 2019; Similarity Check in January 2019; Accepted in November 2019]

Chronic smokers often claim that smoking improves their cognitive abilities, such as concentration. However, scientific evidence to support this claim is scarce. Previous studies gave inconclusive results, and some of them had significant methodological flaws. Therefore, the aim of this study was to test whether smoking a single cigarette affects performance across several cognitive domains. It included a group of 22 occasional smokers aged 19-29 years. Attention, working memory, and visuospatial reasoning were assessed using a within-subjects design with a control setting. There were two separate testing sessions two days apart. Half the group started with experimental and the other half with control setting. In the experimental setting, the participants completed the first block of tasks, smoked one cigarette (with a nicotine yield of $0.5 \mathrm{mg}$ ), and then completed the second block of tasks. In the control setting, the procedure was the same, except that the participants had a glass of water instead of a cigarette. Repeated measures ANOVA showed no significant effects of cigarette smoking on either reaction time rates or accuracy on any of the three cognitive domains. These results suggest that, at least among young, occasional smokers, smoking does not affect cognition and the claims of its improvement are probably a result of some sort of cognitive bias.

KEY WORDS: attention; mental rotation; nicotine; smoking; working memory

Smokers often claim that in addition to relaxing effects, smoking improves their cognitive abilities (1-3). Some earlier studies suggest that smoking indeed improves cognitive performance, but many of them had flawed design (4). For example, the participants were smokers who were tested after a certain period of deprivation, and their performance was then compared with the performance on the same tasks after smoking. Since abstinence symptoms can cause emotional, physical, and cognitive difficulties (5), it cannot be determined whether improved performance after smoking reflected the actual effect of nicotine or only the participants' normal performance, once the abstinence symptoms were removed. Some studies lacked ecological validity, as nicotine was not smoked but administered through the transdermal or intranasal route, and their findings are not comparable with the smoking studies due to huge variations in nicotine doses (4).

Nicotine activates nicotinic acetylcholine receptors (nAChRs) (6), which are highly represented in the cortical and subcortical areas of the brain. By binding to specific cellular and substrate $\mathrm{nAChR}$ subtypes, nicotine modulates the activity of different types of neurons in the neuronal network (7). In addition to facilitating the release of acetylcholine, nicotine also facilitates the release of

Corresponding author: Ivana Hromatko, Department of Psychology, Faculty of Humanities and Social Sciences, University of Zagreb, Lučićeva 3, 10000 Zagreb, Croatia. E-mail: ivana.hromatko@ffzg.hr dopamine, serotonin, glutamate, and other neurotransmitters involved in cognitive processes, including attention, working memory, and visuospatial reasoning (5).

Attention processes are strongly linked to acetylcholine signalling in the prefrontal cortex (PFC). Nicotine has been shown to increase acetylcholine activity in the PFC, which suggests that it might have a positive effect on attention (7, $8)$. One study showed that nicotine enhanced reaction time (9) and another accuracy of response (10) in the rapid visual information processing (RVIP) task. Furthermore, nicotine seems to de-activate certain brain regions that need to be de-activated to successfully solve the RVIP task (8) and therefore to facilitate focusing of cognitive resources on a specific task. Similar effects were reported for the continuous performance task $(11,12)$, vigilance, and selective attention. However, these effects varied significantly with the type and difficulty of the tasks (13, 14). Studies in clinical populations are particularly interesting, as they showed a promising potential of nicotine for therapeutic purposes by improving performance in patients with ADHD (12) and schizophrenia (15).

As for working memory, a large number of nicotine receptors were found in the hippocampus, which suggests that nicotine could also influence memory (16). Several studies conducted mostly on rodents confirmed this hypothesis $(17,18)$. The most significant improvements after nicotine treatment were seen in spatial working 
memory tasks (e.g. radial labyrinth). Although this effect has repeatedly been confirmed in animals, the results are rather inconsistent in humans $(3,9,19-22)$. However, these studies were conducted on deprived smokers, and it is impossible to exclude abstinence symptoms as the confounding factor. Ernst et al. (23) compared smokers and former smokers (who had not smoked for 6.5 years before entering the study) and found no effect of nicotine in former smokers. They also monitored brain activity during task solving and found that smokers had higher activity in the right hemisphere, while non-smokers had higher activity in the left hemisphere, which suggests that chronic exposure to nicotine or withdrawal from nicotine affects cognitive strategies used to perform a memory task.

Since spatial reasoning mainly activates the right brain (24-34) and since nicotine increases right brain activity as well, nicotine might also influence visuospatial reasoning. Several animal and human studies have investigated this effect of nicotine on spatial working memory $(17,18,35$, 36) and yielded inconsistent results. Studies of nicotine effects on visuospatial reasoning, in turn, remain few and inconclusive. In an EEG study, Iwaki et al. (37) reported minimal improvement in the reaction time and the number of correct answers between the experimental (cigarette smoking) and control setting (a break without smoking) in 12 study participants. However, the lateralization (greater right hemisphere activity) was significantly higher after the experimental treatment. Neumann et al. (38) also explored possible sex differences, and found that, contrary to Iwaki et al. (37), nicotine prolonged reaction times in the mental rotation tasks, which was even more pronounced in women than men. They suggested that men are more resistant to the effect of nicotine due to their general superiority in mental rotations.

Mental rotations are the most complex type of spatial abilities, involving many different areas of the brain, and various cognitive processes. It is very likely that attention has an important role in these processes (39), especially the ability to maintain attention over a longer time. Therefore, it seems plausible that nicotine affects performance on mental rotation tasks through attention-allocating processes (11-13).

In summary, given the inconsistencies and methodological flaws of earlier research, it is still not clear which, if any, of the cognitive functions are affected by nicotine. Therefore, the aim of this study was to exclude withdrawal/abstinence symptoms as a confounding factor by testing the effects of smoking one cigarette in a group of occasional smokers without withdrawal symptoms. Furthermore, we tested their performance in three cognitive domains: working memory, attention, and spatial reasoning. We chose these domains in an attempt to differentiate between direct effects of nicotine on certain complex cognitive processes (such as spatial reasoning, measured here via mental rotations) and its potential indirect effects (e.g. by enhancing underlying cognitive processes, such as attention and working memory).

\section{PARTICIPANTS AND METHODS}

\section{Participants}

The study included 22 participants (20 women and two men) aged 19-29 years (mean $\pm \mathrm{SD}=22.2 \pm 2.35)$. They were tested individually, after signing an informed consent. The procedure followed the Ethical Code of Conduct of the Croatian Psychological Association and the guidelines of the Declaration of Helsinki. All participants were occasional smokers, who smoked less than one cigarette a day. Fifteen smoked up to 15 cigarettes a month, and seven smoked one to five cigarettes a week. Sixteen smoked exclusively during a night out, and six also smoked in stressful situations (e.g. exams). At the first meeting, participants filled a sociodemographics background questionnaire, and their anonymity was ensured by replacing personal information with a unique code. All participants declared that they were healthy.

\section{Study design}

The protocol for each testing session was the same: in the first session the participants completed the first trial (pretest), then had a short break during which they smoked one cigarette (experimental setting) or drank a glass of water (control setting) and then completed the second trial (posttest). In the second session, two days later, they did the same tasks again, but if they had smoked a cigarette during the first session, now they had to drink water (Figure 1). All the participants were given the same brand of cigarettes, which yields $0.5 \mathrm{mg}$ of nicotine and $6 \mathrm{mg}$ of tar. This amount of nicotine was selected because these occasional smokers were not used to larger amounts and we wanted to avoid the risk of inducing adverse side effects.

We opted for a within-subject design in which all participants were exposed to all conditions, so that individual differences would not distort the results. Each participant served as his/her own baseline. Furthermore, within-subject designs have greater statistical power than between-subjects designs (takes fewer participants to show a significant effect if there is one). The reason for this is that repeated measures ANOVA separates individual variance from the rest of the error variance. Thus, the total variance in the within-subject analysis is comprised of treatment variance, between-subjects variance, and error variance. By separating between-subjects variance, we reduced the amount of error variance in the equation, allowing for greater internal validity of the study. To avoid a potential limitation of a repeated measures design and of the learning effect (enhanced performance is expected on subsequent trials of most cognitive tests), we counterbalanced the order of sessions for all participants. 
Session 1

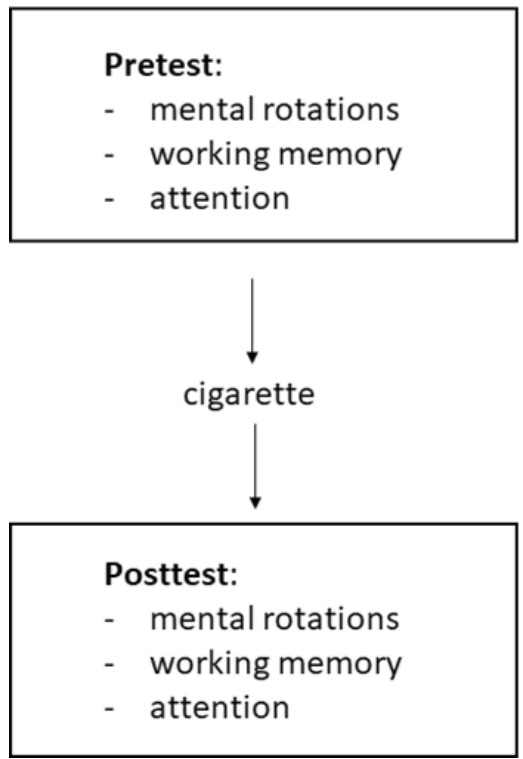

Figure 1 Experimental design

\section{Testing}

We used E-prime 2.0 (Psychology Software Tools, Inc., Pittsburgh, PA, USA) (40) to run the tests and collect participants' responses.

\section{Mental rotation task}

Participants were first shown a fixation cross (for $500 \mathrm{~ms}$ ) which was then followed by a letter (F, G, L, N, P, or R), which was either rotated, mirrored, or rotated and mirrored. They had to press " 1 " on the keyboard if the letter was mirrored, "0" if the letter was just rotated or shown normally (Figure 2). The letter would stay on the screen for no more than ten seconds (or less if the participant responded sooner) after which the next item was loaded. The task had 50 items and lasted about two minutes.

\section{Working memory task}

We used a modified version of Experiment 1 described by Vogel et al. (41). Participants were briefly shown red

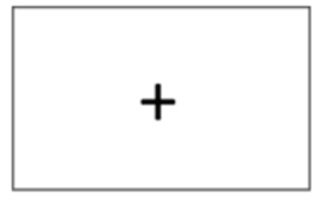

$500 \mathrm{~ms}$

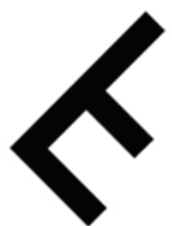

$\max 10 \mathrm{~s}$
Figure $2 \mathrm{An}$ item in the mental rotations task: letter $\mathrm{F}$ is both mirrored and rotated

\section{Session 2}

Pretest:

- mental rotations

- working memory

- attention

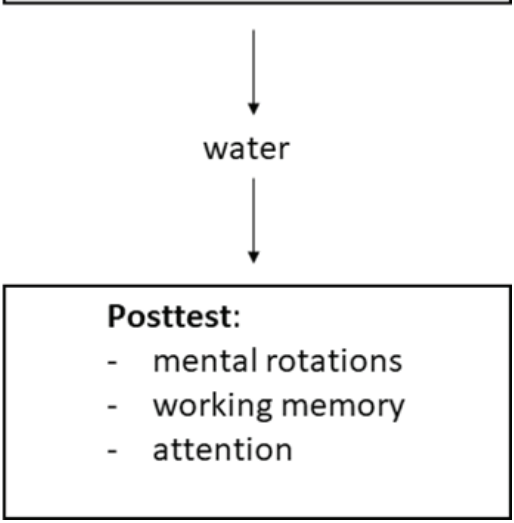

and blue rectangles at various angles. They had to memorise the position of the rectangles indicated by the arrow and then, when the next picture was shown, respond if the two pictures were identical or if they differed. Participants were first shown a fixation cross $(400 \mathrm{~ms})$ with an arrow indicating on which side of the screen they should focus, followed by the first picture with rectangles $(300 \mathrm{~ms})$, then again a fixation cross $(500 \mathrm{~ms})$, and then the second picture with rectangles (Figure 3 ). The participants had to press " 1 " if the second picture was the same as the first one or " 0 " if the pictures were different. The second picture was displayed for no more than 10 seconds. The task had 96 items and lasted about four minutes.

\section{Attention task}

Participants were first shown a fixation cross $(1 \mathrm{~s})$, then a letter of the alphabet ( $1 \mathrm{~s})$, then again a fixation cross ( $1 \mathrm{~s})$, and then a letter ( $1 \mathrm{~s})$. They had to press " 1 " if the second letter was letter "X" which was preceded by letter " $A$ ". If any other combination of letters appeared on the screen, participants had to press "0" (Figure 4). Two sets of letters were separated by a pause, which lasted either $1500 \mathrm{~ms}$, $2000 \mathrm{~ms}$, or $2500 \mathrm{~ms}$. The durations of the pause were randomised. The task had 45 items and lasted for about three and a half minutes.

\section{Statistical analysis}

All data analyses and statistical procedures were carried out with the IBM SPSS Statistics v. 25 (Armonk, NY, USA). We used the repeated measures ANOVA to analyse reaction time and accuracy (dependent variables) in relation to setting (experimental vs. control) and trial (pretest vs. posttest). The rationale for this procedure was that we 


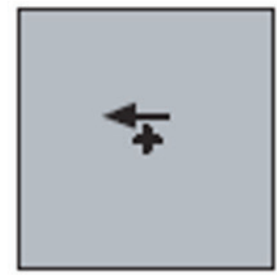

$400 \mathrm{~ms}$

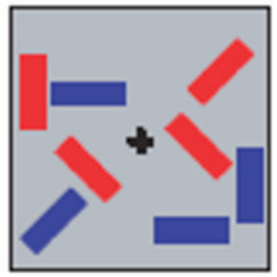

$300 \mathrm{~ms}$

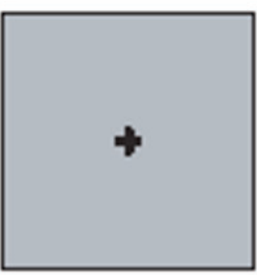

$500 \mathrm{~ms}$

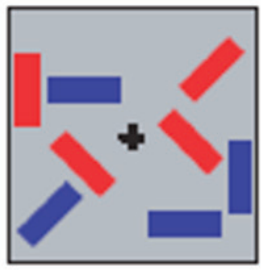

$\max 10 \mathrm{~s}$

Figure $3 \mathrm{An}$ item in the working memory task

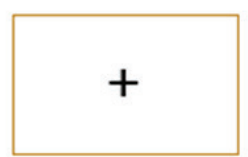

Is

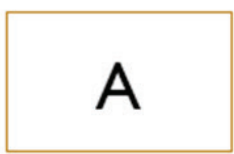

Is

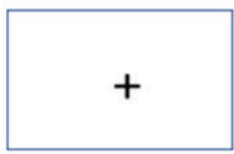

Is

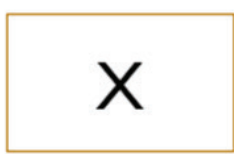

Is

Figure $4 \mathrm{An}$ item in the attention task

expected a significant main effect of trial (i.e. better performance at posttest as compared to pretest), but also wanted to test for an interaction effect between setting and trial. If there was an enhancing effect of smoking on performance, then the pretest-posttest increase in participants' scores would be significantly larger in the experimental setting as compared to the control setting.

First we ran it for the female participants only and then included the responses of the two male participants and repeated the analysis. As this inclusion did not change the results, their data were kept in the analysis.

\section{RESULTS}

\section{Mental rotation}

ANOVA showed no significant effects of cigarette smoking (vs. water) on either reaction times (ms) or on the number of correct answers (Figures 5 and 6, Table 1). Participants were significantly faster at posttest, regardless of whether they drank water or smoked a cigarette during the break, but did not significantly improve the number of correct answers (Table 1).

\section{Working memory}

Regardless of the setting (experimental or control), participants were significantly faster (ms) and had significantly

more correct answers in the posttest than in pretest (Figures 7 and 8, Table 2). However, there were no significant differences between settings (experimental vs. control) and no significant interaction (setting $\mathrm{x}$ trial) (Table 2).

\section{Attention}

In both the experimental and control settings, participants were significantly faster (ms) in the posttest than pretest (Figure 9). Neither the main effect of the setting (experimental vs. control) nor the interaction (setting $\mathrm{x}$ trial) were significant (Table 3 ). The number of correct answers hit the ceiling (accuracy was at $96 \%$ in the pretest of the first session and $97.8 \%$ in subsequent trials; Figure 10), so there were no significant effects of either treatment, trial, or their interaction. Figure 6 also shows that one participant consistently had a lower accuracy, so the analysis was repeated without that participant, but that exclusion did not change the results.

\section{DISCUSSION}

The main aim of this study was to test the assumption that smoking of a single cigarette would improve attention, working memory, and visuospatial reasoning, and our results showed no such effect.

Table 1 Mental rotations: repeated measures analysis of variance with setting (experimental vs. control) and trial (pretest vs. posttest) as sources of variance and reaction time and accuracy as dependent variables

\begin{tabular}{lcccccccc}
\hline & \multicolumn{9}{c}{ Reaction time } & \multicolumn{4}{c}{ Accuracy } \\
\hline Variable & $\mathrm{F}$ & $\mathrm{df}$ & $\mathrm{P}$ & Partial $\eta^{2}$ & $\mathrm{~F}$ & $\mathrm{df}$ & $\mathrm{P}$ & Partial $\eta^{2}$ \\
\hline Trial (A) & 26.832 & $(1,21)$ & $0.000^{* *}$ & 0.561 & 0.017 & $(1,21)$ & 0.897 & 0.001 \\
\hline Setting (B) & 0 & $(1,21)$ & 0.985 & 0.000 & 0.738 & $(1,21)$ & 0.400 & 0.034 \\
\hline $\mathrm{A} * \mathrm{~B}$ & 0.787 & $(1,21)$ & 0.385 & 0.036 & 0.631 & $(1,21)$ & 0.436 & 0.029 \\
\hline
\end{tabular}

$* \overline{\mathrm{P}<.05 ; * * \mathrm{P}<.01}$ 


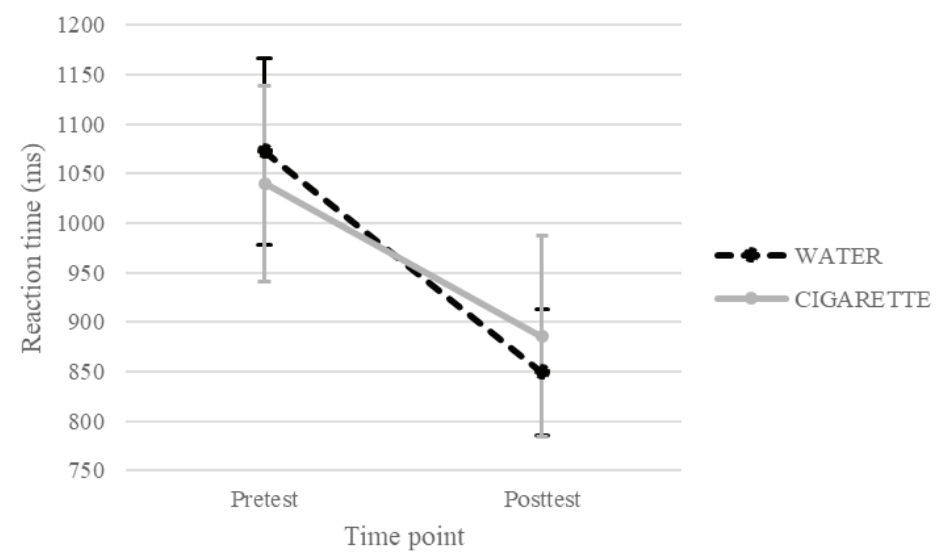

Figure 5 Mental rotation: mean reaction time (ms) for each experimental setting $(\mathrm{N}=22)$

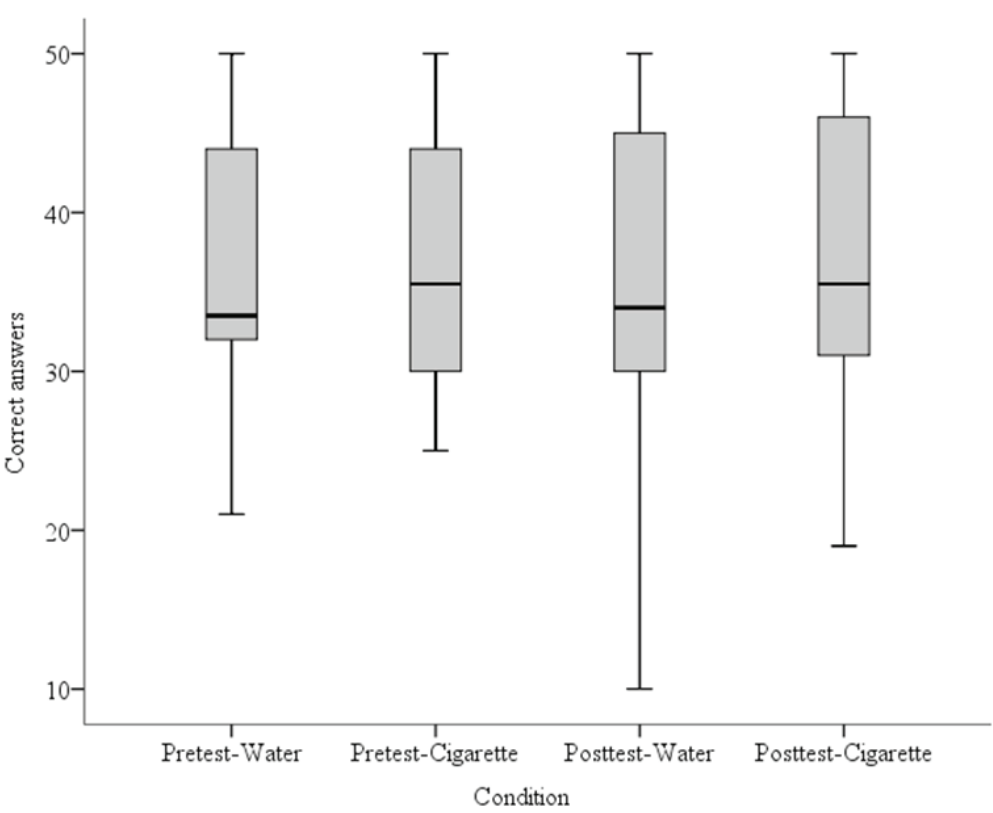

Figure 6 Mental rotation: number of correct answers for each experimental setting $(\mathrm{N}=22)$

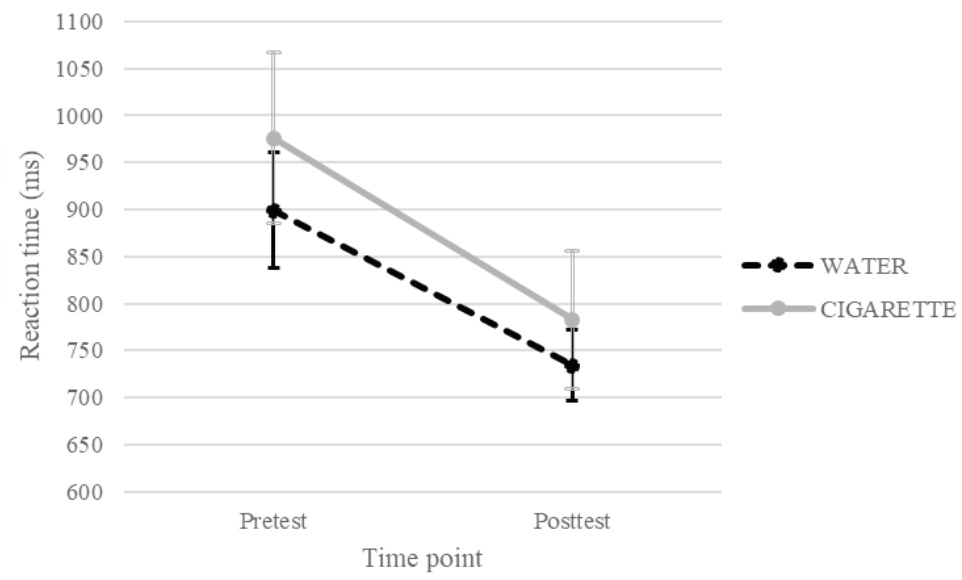

Figure 7 Working memory: mean reaction time $(\mathrm{ms})$ for each experimental setting $(\mathrm{N}=22)$ 
Table 2 Working memory: repeated measures analysis of variance with setting (experimental vs. control) and trial (pretest vs. posttest) as sources of variance and reaction time and accuracy as dependent variables

\begin{tabular}{lcccccccccc}
\hline & \multicolumn{4}{c}{ Reaction time } & \multicolumn{3}{c}{ Accuracy } \\
\hline Variable & $\mathrm{F}$ & $\mathrm{df}$ & $\mathrm{P}$ & Partial $\eta^{2}$ & $\mathrm{~F}$ & $\mathrm{df}$ & $\mathrm{P}$ & $\mathrm{Partial} \eta^{2}$ \\
\hline Trial (A) & 31.119 & $(1,21)$ & $0.000 * *$ & 0.597 & 6.777 & $(1,21)$ & $0.017 *$ & 0.244 \\
\hline Setting (B) & 0.511 & $(1,21)$ & 0.482 & 0.024 & 0.304 & $(1,21)$ & 0.587 & 0.014 \\
\hline $\mathrm{A} * \mathrm{~B}$ & 0.210 & $(1,21)$ & 0.651 & 0.01 & 0.210 & $(1,21)$ & 0.571 & 0.016 \\
\hline $\mathrm{P}<0.05 ; * * \mathrm{P}<0.01$ & & & & & & &
\end{tabular}

Table 3 Attention: repeated measures analysis of variance with setting (experimental vs. control) and trial (pretest vs. posttest) as sources of variance and reaction time and accuracy as dependent variables

\begin{tabular}{lllllllll}
\hline \multicolumn{3}{l}{ Reaction time } & \multicolumn{7}{c}{ Accuracy } \\
\hline Variable & $\mathrm{F}$ & $\mathrm{df}$ & $\mathrm{P}$ & Partial $\eta^{2}$ & $\mathrm{~F}$ & $\mathrm{df}$ & $\mathrm{P}$ & Partial $\eta^{2}$ \\
\hline Trial (A) & 12.573 & $(1,21)$ & $0.002 *$ & 0.374 & 2.967 & $(1,21)$ & 0.100 & 0.124 \\
\hline Setting (B) & 0.77 & $(1,21)$ & 0.39 & 0.035 & 0.884 & $(1,21)$ & 0.358 & 0.040 \\
\hline $\mathrm{A} * \mathrm{~B}$ & 0.354 & $(1,21)$ & 0.558 & 0.017 & 1.067 & $(1,21)$ & 0.313 & 0.048 \\
\hline $\mathrm{P}<0.05 ; * * \mathrm{P}<0.01$ & & & & & & &
\end{tabular}

In the majority of earlier studies, the route of nicotine administration was subcutaneous (injection), transdermal (patch), buccal (nicotine chewing gum), or intranasal (spray). These routes deliver higher nicotine doses than smoking. In other words, the lack of effect in this study may be related to the route (smoking) and dose $(0.5 \mathrm{mg})$ of nicotine administered. Declarations on most cigarette brands on the market state that they yield from 0.1 to $1.1 \mathrm{mg}$ of nicotine, which has been confirmed by independent reports (42). The nicotine dose used in this study may have been too low to cause any effect $(3,43)$. Another possible explanation for the lack of differences between cigarette vs. control setting is that the control setting (water drinking) may have had an expectancy effect. But again, this would only suggest that the effect of one cigarette, contrary to popular belief, is no greater than that of a placebo.

Attention has previously been shown as the most susceptible to the effects of nicotine $(9,12-14)$. However, ours is not the first study to show no significant effect (20, $21,44)$. Some authors $(13,14)$ suggest that the effect of nicotine on attention could be a function of task complexity, and that the best improvement is achieved in tasks of medium difficulty. Admittedly, however, our participants found this task too easy and achieved the score plateau during the first session, leaving little room for improvement. Even so, the improvement in performance would have been detected in reduced reaction times, but there was no significant effect of nicotine on those either. Future studies might address this issue by using tasks of various levels of difficulty within the same cognitive domain in order to elucidate this possibly non-linear correlation. The time needed to complete the task should also be considered. In our case, the task lasted about four minutes, but the effect of nicotine, if there is one, might become evident in longer tasks.

The only significant effect we found in the working memory test was the improvement in repeated trials. These results are consistent with some previous studies (21-23).
As there is a lack of information regarding the possible effect of nicotine on visuospatial working memory in humans, we focused specifically on this component of working memory (as participants had to memorise and recognise specific locations of rectangles in the working memory task). Some previous findings $(8,23,37)$ suggest that smokers prefer visual strategies (storing and processing information in a visual or spatial form, i.e. using a visuospatial sketchpad) and ex-smokers prefer phonological strategies (storing and processing information in a form of spoken and written material, i.e. using a phonological loop). While these results suggest that smokers might have an advantage in solving complex visuospatial tasks, there is not enough evidence to confirm that or to pinpoint the neural mechanism underlying this nicotine-induced lateralisation shift. However, the notion that smokers have an increased activation of the areas in the right brain that are associated with visuospatial abilities seemed worth investigating, which is why we tested performance on a mental rotation task and a working memory task with a visuospatial component. Again, with each repetition of the task, the participants had a faster response to the stimulus, but the number of correct answers did not change.

\section{Limitations and strengths of this study}

This study had a relatively small sample size. This is not unusual in this type of research, as majority of previously published studies had about 20 participants. However, larger and gender-balanced samples would make conclusions more generalisable. Furthermore, our group of participants may have been heterogeneous regarding their smoking habits (e.g. some are exclusively "social smokers", others smoke when they work/study) and their smokingrelated beliefs.

As discussed above, unlike other means of delivery (e.g. intranasal spray) smoking does not allow for a precise control of the amount of nicotine being delivered. Also, 


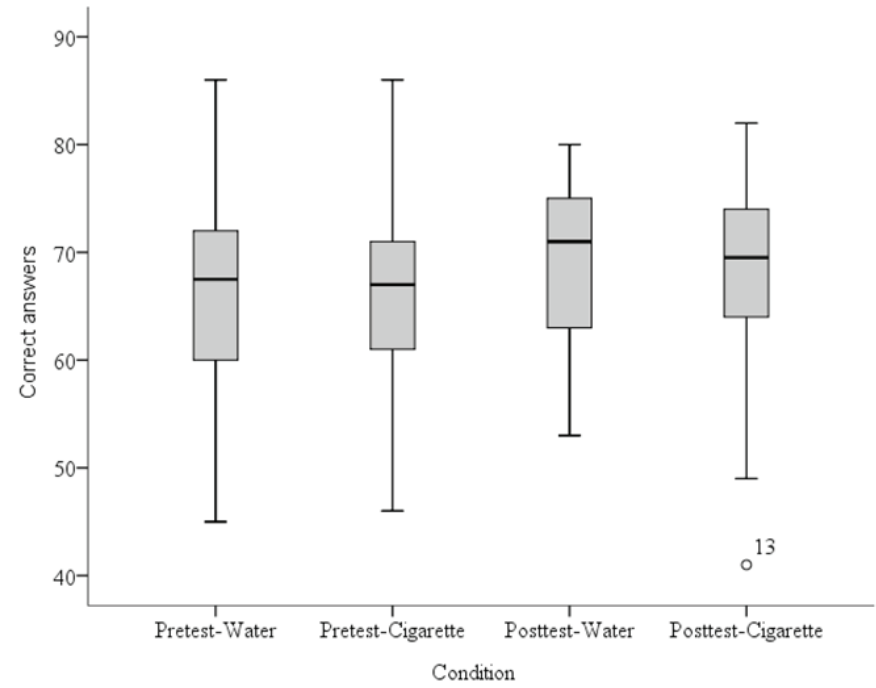

Figure 8 Working memory: number of correct answers for each experimental setting ( $\mathrm{N}=22)$

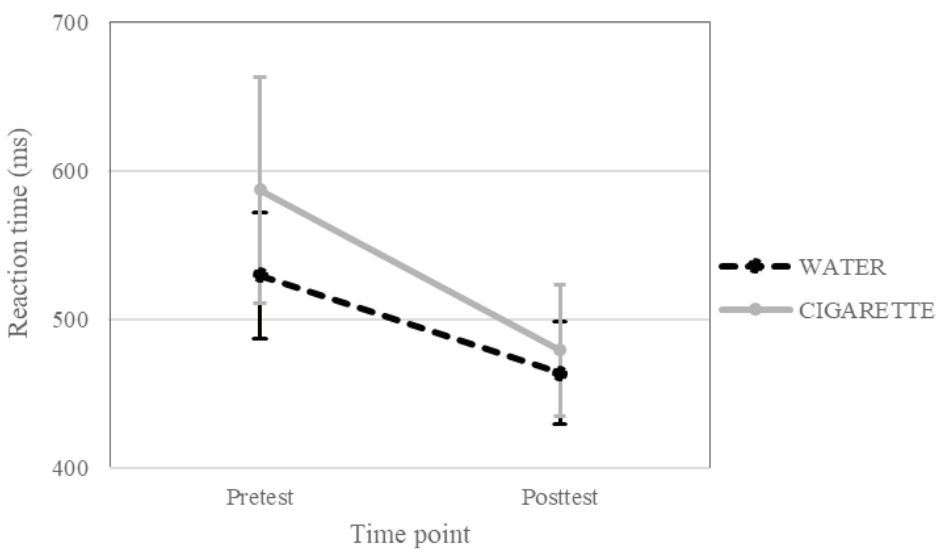

Figure 9 Attention: mean reaction time (ms) for each experimental setting $(\mathrm{N}=22)$

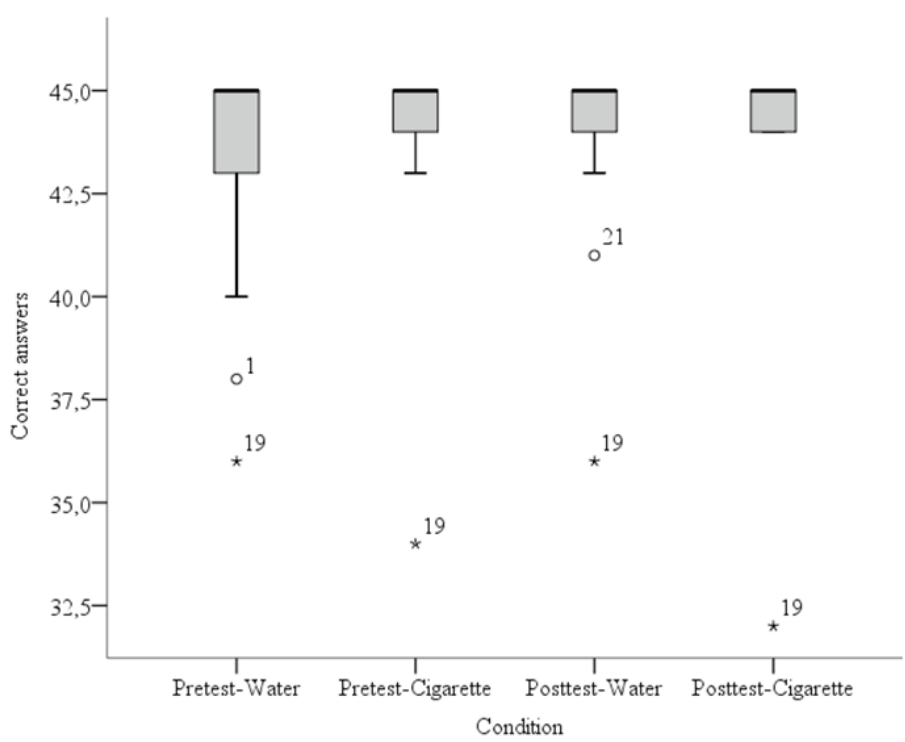

Figure 10 Attention: number of correct answers for each experimental setting $(\mathrm{N}=22)$ 
other ingredients (e.g. tar) in the cigarette may have interfered with the effect of nicotine. Furthermore, we did not control for the duration of the cigarette break, i.e. the participants were asked to smoke the cigarette at their usual pace. The puff rate can influence the plasma nicotine concentration, i.e. the faster the rate, the higher the nicotine concentration. In other words, administering nicotine through cigarette smoking is rather imprecise in terms of dosage. A dose-dependent study design might provide a more meaningful information regarding the specific effects of nicotine on cognition.

These shortcomings notwithstanding, we believe that the choice of occasional smokers is one of the main advantages of this study, as it overcomes the problem pertinent to chronic smokers of distinguishing between the effects of nicotine and withdrawal symptoms on cognitive performance (4). Occasional smokers have a certain tolerance for negative nicotine effects and are unlikely to suffer from withdrawal symptoms. Similarly, unlike some other routes of administration smoking adds to the ecological validity of the study - most people inhale and not inject themselves with nicotine. An additional advantage of this research is the use of a full experimental design, i.e. the pre-posttest control, contributing to a greater internal validity of the experiment.

Furthermore, ours was one of the few studies that dealt with visuospatial reasoning, and even though no significant effect of nicotine was found in this domain, it has singled out potentially relevant variables (e.g. sex differences, lateralisation, and the frequency of cigarette use in everyday life) and suggested directions for future research in this domain.

\section{CONCLUSION}

Taken together, our results suggest that the effect of cigarettes on cognition is probably subjective. People tend to believe that a cigarette shall have some beneficial effect (e.g., help them relax and/or improve their concentration). In other words, cigarettes may have a placebo effect. It is also possible that nicotine does improve performance on some tasks, but, in reality, this effect is small at best. Furthermore, cigarettes may indirectly influence cognitive performance through mood enhancement and general activation. A small number of studies dealt with these aspects, and future research should focus more on it in order to determine the potential indirect effects of nicotine. Given the inconsistency and lack of significant effect in many human studies, it seems likely that self-reported enhancement in cognitive functions is a result of various cognitive biases (such as confirmation bias and illusory correlation), at least among young, occasional smokers. Self-reports are notoriously prone to errors in judgement and such errors might have a role in maintaining the smoking habit.

\section{Conflicts of interest}

None to declare.

\section{REFERENCES}

1. World Health Organization (WHO). Global report on trends in prevalence of tobacco smoking: Prevalence of tobacco smoking 2015 [displayed 24 January 2018]. Available at https://apps. who.int/iris/bitstream/handle/10665/156262/9789241564922 e $\mathrm{n} g$. p d f; j s e s s i o n i d= 35 A 9 E 5884 B 89 550AA678B616550FE249? sequence $=1$

2. West R. Beneficial effects of nicotine: fact or fiction? Addiction 1993;88:589-90. doi: 10.1111/j.1360-0443.1994.tb00868.x

3. Heishman SJ, Taylor RC, Henningfield JE. Nicotine and smoking: A review of effects on human performance. Exp Clin Psychopharmacol 1994;2:345-95. doi: 10.1037/10641297.2.4.345

4. Heishman SJ, Kleykamp BA, Singleton EG. Meta-analysis of the acute effects of nicotine and smoking on human performance. Psychopharmacology (Berl) 2010;210:453-69. doi: 10.1007/ s00213-010-1848-1

5. Di Matteo V, Pierucci M, Di Giovanni G, Benigno A, Esposito E. The neurobiological bases for the pharmacotherapy of nicotine addiction. Curr Pharm Des 2007;13:1269-84. doi: 10.2174/138161207780618920

6. Poorthuis RB, Goriounova NA, Couey JJ, Mansvelder HD. Nicotinic actions on neural networks for cognition: General principles and long-term consequences. Biochem Pharmacol 2009;78:668-76. doi: 10.1016/j.bcp.2009.04.031

7. Mansvelder HD, van Aerde KI, Couey JJ, Brussaard AB. Nicotinic modulation of neuronal networks: from receptors to cognition. Psychopharmacology (Berl) 2006;184:292-305. doi: 10.1007/s00213-005-0070-z

8. Lawrence NS, Ross TJ, Stein EA. Cognitive mechanisms of nicotine on visual attention. Neuron 2002;36:539-48. doi: 10.1016/s0896-6273(02)01004-8

9. Foulds J, Stapleton J, Swettenham J, Bell N, McSorley K, Russel MAH. Cognitive performance effects of subcutaneous nicotine in smokers and never-smokers. Psychopharmacology (Berl) 1996;127:31-8. doi: 10.1007/bf02805972

10. File SE, Fluck E, Leahy A. Nicotine has calming effects on stress-induced mood changes in females, but enhances aggressive mood in males. Int J Neuropsychopharmacol 2001;4:371-6. doi: 10.1017/S1461145701002577

11. Levin ED, Conners CK, Silva D, Hinton SC, Meck WH, March J, Rose JE. Transdermal nicotine effects on attention. Psychopharmacology (Berl) 1998;140:135-41. doi: 10.1007/ s002130050750

12. Poltavski DV, Petros T. Effects of transdermal nicotine on attention in adult non-smokers with and without attentional deficits. Physiol Behav 2006;87:614-24. doi: 10.1016/j. physbeh.2005.12.011

13. Hahn B, Thomas RJ, Wolkenberg FA, Shakleya DM, Huestis MA, Stein EA. Performance effects of nicotine during selective attention, divided attention, and simple stimulus detection: an fMRI study. Cereb Cortex 2009;19:1990-2000. doi: 10.1093/ cercor/bhn226

14. Smucny J, Ollncy A, Eichman LS, Tregellas JR. Neuronal effects of nicotine during auditory selective attention. 
Psychopharmacology 2015;232:2017-28. doi: 10.1007/s00213014-3832-7

15. Barr RS, Culhane MA, Jubek LE, Mufti RS, Dyer MA, Weiss AP, Deckersbach T, Kelly JF, Freudenreich O, Goff DC, Evins AE. The effects of transdermal nicotine on cognition in nonsmokers with schizophrenia and nonpsychiatric controls. Neuropsychopharmacology 2008;33:480-90. doi: 10.1038/ sj.npp. 1301423

16. Rezvani AH, Levin ED. Cognitive effects of nicotine. Biol Psych 2001;49:258-67. doi: 10.1016/S0006-3223(00)01094-5

17. Levin ED. Nicotinic agonist and antagonist effects on memory. Drug Dev Res 1996;38:188-95. doi: 10.1002/(SICI)10982299(199607/08)38:3/43.0.CO;2-I

18. Levin ED, Simon BB. Nicotinic acetylcholine involvement in cognitive functions in animals. Psychopharmacology (Berl) 1998;138:217-30. doi: 10.1007/s002130050667

19. Kumari V, Gray JA, Ffytche DH, Mitterschiffthaler MT, Das M, Zachariah E, Vythelingum GN, Williams SCR, Simmons A, Sharma T. Cognitive effects of nicotine in humans: an fMRI study. NeuroImage 2003;19:1002-13. doi: 10.1016/S10538119(03)00110-1

20. Heishman SJ, Henningfield JE. Tolerance to repeated nicotine administration on performance, subjective, and physiological responses in nonsmokers. Psychopharmacology (Berl) 2000;152:321-33. doi: 10.1007/s002130000541

21. Kleykamp BA, Jennings JM, Blank MD, Eissenberg T. The effects of nicotine on attention and working memory in neversmokers. Psychol Addict Behav 2005;19:433-8. doi: 10.1037/0893-164X.19.4.433

22. Myers CS, Taylor RC, Moolchan ET, Heishman SJ. Dose-related enhancement of mood and cognition in smokers administered nicotine nasal spray. Neuropsychopharmacology 2008;33:58898. doi: 10.1038/sj.npp.1301425

23. Ernst M, Matochik JA, Heishman SJ, Van Horn JD, Jons PH, Henningfield JE, London ED. Effect of nicotine on brain activation during performance of a working memory task. PNAS 2001;98:4728-33. doi: 10.1073/pnas.061369098

24. Michel CM, Kaufman L, Wiliamson SJ. Duration of EEG and MEG $\alpha$ suppression increases with angle in a mental rotation task. J Cogn Neurosci 1994;6:139-50. doi: 10.1162/ jocn.1994.6.2.139

25. Cohen MS, Kosslyn SM, Breiter HC, DiGirolamo GJ, Thompson WL, Andreson AK, Brookheimer SY, Rosen BR, Belliveau JW. Changes in cortical activity during mental rotation. A mapping study using functional MRI. Brain 1996;119:89-100. doi: 10.1093/brain/119.1.89

26. Alivisatos B, Petrides M. Functional activation of human brain during mental rotation. Neuropsychologia 1997;35:111-8. doi: 10.1016/S0028-3932(96)00083-8

27. Serrati C, Finnocchi C, Calautti C, Bruzzone GL, Colucci M, Gandolfo C, Del Sette M, Lantieri PB, Favale E. Absence of hemispheric dominance for mental rotation ability: A transcranial Doppler study. Cortex 2000;36:415-25. doi: 10.1016/s00109452(08)70850-5

28. Richter W, Somorjai R, Summers R, Jarmasz M, Menon RS, Gati JS, Georgopolus AP, Tegler C, Ugurbil K, Kim SG. Motor area activity during mental rotation studied by time-resolved single-trial fMRI. J Cogn Neurosci 2000;12:310-20. doi: $10.1162 / 089892900562129$

29. Cabeza R, Nyberg L. Imaging condition II: An empirical review of 275 PET and fMRI studies. J Cogn Neurosci 2000;12:1-47. doi: $10.1162 / 08989290051137585$
30. Jordan K, Heinze HJ, Lutz K, Kanowski M, Jäncke L. Cortical activations during the mental rotation of different visual objects. NeuroImage 2001;13:143-52. doi: 10.1006/nimg.2000.0677

31. Michel CM, Thut G, Morand S, Khateb A, Pegna AJ, Grave de Peralta R, Gonzalez S, Seeck M, Landis T. Electric source imaging of human brain functions. Brain Res Rev 2001;36:108 18. doi: 10.1016/S0165-0173(01)00086-8

32. Ark WS. Neuroimaging studies give new insight to mental rotation. Proceedings of the $35^{\text {th }}$ Hawaii International Conference on System Sciences 2002 [displayed 1 October 2019]. Available at http://citeseerx.ist.psu.edu/viewdoc/ download?doi=10.1.1.575.1493\&rep=rep1\&type=pdf

33. Levin SL, Mohamed FB, Platek SM. Common ground for spatial cognition? A behavioural and fMRI study of sex differences in mental rotation and spatial working memory. Evol Psychol 2005;3:227-54. doi: 10.1177/147470490500300116

34. Luo H, Ni JT, Li ZH, Li XO, Zhang DR, Zeng FG, Chen L. Opposite patterns of hemisphere dominance for early auditory processing of lexical tones and consonants. PNAS 2006;103:19558-63. doi: 10.1073/pnas.0607065104

35. Vossel S, Thiel CM, Fink GR. Behavioral and neural effects of nicotine on visuospatial attentional reorienting in non-smoking subjects. Neuropsychopharmacology 2008;33:731-8. doi: 10.1038/sj.npp.1301469

36. Bates T, Mangan G, Stough C, Corballis P. Smoking, processing speed and attention in a choice reaction time task. Psychopharmacology (Berl) 1995;120:209-12. doi: 10.1007/ bf02246195

37. Iwaki T, Tamaki M, Hayashi M, Hori T. An exploratory study of effects of smoking on mental rotation and mental paperfolding task. Percept Mot Skills 1998;87:1171-82. doi: 10.2466/ pms.1998.87.3f.1171

38. Neumann DL, Fitzgerald ZT, Furedy JJ, Boyle GJ. Sexually dimorphic effects of acute nicotine administration on arousal and visual-spatial ability in non-smoking human volunteers. Pharmacol Biochem Behav 2007;86:758-65. doi: 10.1016/j. pbb.2007.03.001

39. Smith AP, Rusted JM, Eaton-Williams P, Savory M, Leathwood P. Effects of caffeine given before and after lunch on sustained attention. Neuropsychobiology 1990;23:160-3. doi: $10.1159 / 000119444$

40. Psychology Software Tools. E-Prime 2.0 Reference Guide Manual, 2012 [displayed 1 October 2019]. Available at http:// psy.swan.ac.uk/staff/lucignoli/E-Prime/ ReferenceGuideV2 2012.pdf

41. Vogel EK, McCollough AW, Machizawa MG. Neural measures reveal individual differences in controlling access to working memory. Nature 2005;438:500-3. doi: 10.1038/nature04171

42. Government Laboratory of the Government of the Hong Kong Special Administrative Region. Tar and Nicotine Report 2018 [displayed 3 August 2019]. Available at https://www.govtlab. gov.hk/english/pub tnrpt.htm

43. Pritchard WS, Robinson JH, Guy TD. Enhancement of continuous performance task reaction time by smoking in nondeprived smokers. Psychopharmacology (Berl) 1991:108;43742. doi: 10.1007/bf02247417

44. Ernst M, Heishman SJ, Spurgeon L, London ED. Smoking history and nicotine effects on cognitive performance. Neuropsychopharmacology 2001;25:313-9. doi: 10.1016/ S0893-133X(01)00257-3 


\section{Akutna primjena nikotina ne poboljšava kognitivne funkcije}

Kronični pušači često tvrde da im pušenje, između ostaloga, pozitivno utječe na kognitivne sposobnosti (npr. pomaže im u održavanju koncentracije). Je li doista tako još uvijek nemamo jednoznačan odgovor, budući da su prethodne studije ne samo dale nekonzistentne rezultate nego su bile i metodološki manjkave. Stoga je cilj ovoga istraživanja bio utvrditi utječe li konzumacija jedne cigarete na izvedbu zadataka u nekoliko različitih kognitivnih domena. U istraživanju je sudjelovala skupina povremenih pušača u dobi od 19 do 29 godina. Pomoću računalnog programa E-Prime prezentirani su zadaci koji mjere pažnju, radno pamćenje i obradu vidno-prostornih informacija. Korišten je prije-poslije nacrt, uz kontrolni i eksperimentalni uvjet. Sudionici su iste zadatke rješavali četiri puta: prije i poslije tretmana u kontrolnom uvjetu te prije i poslije tretmana u eksperimentalnom uvjetu. U kontrolnom uvjetu tretman se sastojao od čaše vode koju su sudionici morali popiti, a u eksperimentalnom uvjetu od pušenja jedne cigarete koja otpušta 0,5 mg nikotina. Stanka između kontrolnoga i eksperimentalnoga testiranja bila je dva dana. Redoslijed uvjeta bio je rotiran. Niti u jednom zadatku nije utvrđen značajan utjecaj pušenja ni na vrijeme reakcije ni na točnost rješavanja. Ovi su nalazi u skladu s hipotezom da su samoiskazi o pozitivnom utjecaju pušenja na kognitivnu učinkovitost posljedica neutemeljenih subjektivnih dojmova.

KLJUČNE RIJEČI: mentalne rotacije; nikotin; pažnja; pušenje; radno pamćenje 